Marquette University

e-Publications@Marquette

7-1-2016

Investment Incentives and The Implementation of the Framework Convention On Tobacco Control: Evidence from Zambia

\author{
Raphael Lencucha \\ McGill University \\ Jeffrey Drope \\ Marquette University, jeffrey.drope@marquette.edu \\ Ronald Labonte \\ University of Ottawa \\ Richard Zulu \\ University of Zambia \\ Fastone Goma \\ University of Zambia
}

Accepted version. Tobacco Control, Vol 25, No. 4 (July 2016): 483-487. DOI. (C) 2016, BMJ

Publishing Group. Used with permission. 


\title{
Investment Incentives and The Implementation of the Framework Convention On Tobacco Control: Evidence from Zambia
}

\author{
Raphael Lencucha \\ School of Physical and Occupational Therapy, McGill University, \\ Montreal, Quebec, Canada \\ Jeffrey Drope \\ Economic and Health Policy Research, American Cancer Society, \\ Atlanta, GA \\ Department of Political Science, Marquette University, \\ Milwaukee, WI \\ Ronald Labonte \\ Institute of Population Health, University of Ottawa, \\ Ottawa, Ontario, Canada \\ Richard Zulu \\ Faculty of Medicine, University of Zambia, \\ Lusaka, Zambia \\ Fastone Goma \\ Faculty of Medicine, University of Zambia, \\ Lusaka, Zambia
}

Tobacco Control, Vol 25, No. 4 (July 2016): pg. 483-487. DOI. This article is @ BMJ Publishing Group and permission has been granted for this version to appear in e-Publications@Marquette. BMJ Publishing Group does not grant permission for this article to be further copied/distributed or hosted elsewhere without the express permission from BMJ Publishing Group. 
NOT THE PUBLISHED VERSION; this is the author's final, peer-reviewed manuscript. The published version may be accessed by following the link in the citation at the bottom of the page.

\begin{abstract}
Purpose: Policy misalignment across different sectors of government serves as one of the pivotal barriers to WHO Framework convention on Tobacco Control (FCTC) implementation. This paper examines the logic used by government officials to justify providing investment incentives to increase tobacco processing and manufacturing in the context of FCTC implementation in Zambia.

Methods: We conducted qualitative semi-structured interviews with key informants from government, civil society and intergovernmental economic organizations $(n=23)$. We supplemented the interview data with an analysis of public documents pertaining to economic development policy in Zambia.

Results: We found gross misalignments between the policies of the economic sector and efforts to implement the provisions of the FCTC. Our interviews uncovered the rationale used by officials in the economic sector to justify providing economic incentives to bolster tobacco processing and manufacturing in Zambia: 1) tobacco is not consumed by Zambians/tobacco is an export commodity, 2) economic benefits outweigh health costs, and 3) tobacco consumption is a personal choice.

Conclusions: Much of the struggle Zambia has experienced implementing the FCTC can be attributed to misalignments between the economic and health sectors. Zambia's development agenda seeks to bolster agricultural processing and manufacturing. Tobacco control proponents must understand and work within this context of economic development in order to foster productive strategies with those working on tobacco supply issues. These findings are broadly applicable to the global analysis on the barriers and facilitators of FCTC implementation. It is important that the Ministry of Health monitors the tobacco policy of other sectors and engages with these sectors to find ways of harmonizing FCTC implementation across sectors.
\end{abstract}

Keywords: Economic Policy, Public Policy, Economic Development, Investment Incentives

\title{
Introduction
}

Tobacco control initiatives require coordinated interventions across all sectors of government. The WHO Framework Convention on Tobacco Control (FCTC) implementation requires coordination among government sectors dealing with health, agriculture, trade, industry and finance among others. This requirement is reflected in Article 5.1 of the Treaty: "Each Party shall develop, implement, periodically update and review comprehensive multisectoral national tobacco control ...". ${ }^{1}$ One of the pressing challenges of FCTC implementation is the struggle to enlist the support of the non-health sectors of government who are either disengaged from the issue of tobacco control or actively pursue policies that are misaligned with the

Tobacco Control, Vol 25, No. 4 (July 2016): pg. 483-487. DOI. This article is (C BMJ Publishing Group and permission has been granted for this version to appear in e-Publications@Marquette. BMJ Publishing Group does not grant permission for this article to be further copied/distributed or hosted elsewhere without the express permission from BMJ Publishing Group. 
provisions of the FCTC. ${ }^{2}$ Despite this need, whole-of-government approaches (WoG) to tobacco control have yet to find their place as the modus operandi of most governments. ${ }^{3,4}$ The challenge of WoG is particularly salient in the implementation of the FCTC.

The FCTC is the first public health treaty to be negotiated and ratified under the auspices of the WHO and outlines measures to be implemented by parties to the Convention that serve to reduce the demand for and supply of tobacco. ${ }^{1}$ To date 180 countries are party to the Treaty (as of April 2015). Zambia ratified the FCTC in 2008. Since this time, the Ministry of Health, through the Tobacco Control Focal Point, has worked to implement policies and to establish legislation that aligns with the treaty's commitments and provisions. Post-FCTC legislation was drafted in 2010 but as of April 2015 has not yet been adopted into law. ${ }^{5}$ The challenges of implementation are not unique to Zambia and our multi-country research is uncovering common barriers to implementation among tobacco-growing countries with emerging economies. ${ }^{6}$ One of these barriers relates to incentives to attract domestic and foreign direct investment (FDI). The general logic underlying government investment incentives is twofold. ${ }^{7}$ First, incentives are provided to stimulate economic growth or create value for the country by attracting capital, regardless of its origin, foreign or domestic. ${ }^{8}$ Second, incentives are a means of attracting investment to a country in a competitive global market place, ${ }^{9}$ intended to induce investment that otherwise would not be made.

For Zambia, the pursuit of investment has become central to the political economy of the country's future development. Despite consistent economic growth over the past decade, Zambia continues to struggle with high levels of poverty, income inequality and, in 2012, was ranked 163 of 187 countries on the Human Development Index. ${ }^{10}$ Zambia's economy relies heavily on mineral exports, notably copper. However, since 2002 Zambia has focused on diversifying its economy by supporting the agricultural and service sectors. According to a report by UNCTAD (United Nations Conference on Trade and Development) the "challenge (for Zambia) is to attract more investments in sectors other than mining". ${ }^{11}$ The former president of Zambia, Michael Sata, noted "the aim of (his) government is to continue with policy and institutional reforms with the key objective of making the country more attractive to domestic and foreign private

Tobacco Control, Vol 25, No. 4 (July 2016): pg. 483-487. DOI. This article is (C) BMJ Publishing Group and permission has been granted for this version to appear in e-Publications@Marquette. BMJ Publishing Group does not grant permission for this article to be further copied/distributed or hosted elsewhere without the express permission from BMJ Publishing Group. 
investment". ${ }^{12}$ FDI has increased significantly from $\$ 72$ million (USD) in 2001 to $\$ 1.7$ billion in $2012 .{ }^{13}$ Much of the FDI inflows are tied to the copper sector. The mining sector in general continues to be the largest attractor of FDI (approximately $70 \%$ of total investment pledges in 2008). ${ }^{11}$ Although agriculture only accounted for $22 \%$ of GDP in 2011 it is important for the livelihoods of the majority of Zambians, accounting for approximately $67 \%$ of employment and "has likewise been attracting FDI particularly in the areas of production of horticultural and floricultural products, as well as fruits, cotton, maize, tobacco and sugar". ${ }^{11}$ It is this context of government-supported economic diversification and development that tobacco production, processing and manufacturing are being encouraged through investment incentives, representing a discrepancy between economic goals, and tobacco control commitments. This paper focuses on how these two dissonant goals are rationalized by different actors.

\section{Methods}

The findings presented in this paper are a result of a larger multi-country study in Kenya, Malawi and Zambia. This multi-country case study examines the political economy of tobacco control. The case study methodology is oriented towards using multiple methods to understand a complex phenomenon within a particular context. ${ }^{14,15}$ The findings presented in this paper refer only to our research in Zambia. The findings are derived from data collected through semistructured interviews with representatives from the Department of Industry $(n=3)$, Foreign Affairs $(n=2)$, Foreign Trade $(n=2)$, Agriculture and Agribusiness $(n=5)$, World Health Organization country office $(n=1)$, Ministry of Health $(n=2)$, Tobacco Board of Zambia $(n=1)$, Common Market for Eastern and Southern Africa (COMESA) headquarters $(n=1)$, health-based civil society organizations $(n=3)$ and tobacco industry representatives $(n=3)$. The key informants were identified using purposive sampling and were included because of their involvement in our area of interest, namely the political economy of tobacco and tobacco control. All interviews were conducted in the workplace of the informants by international and Zambian researchers associated with the study. All but two of the interviewees agreed to be recorded. Notes were taken during the interviews with these two participants. Interview length ranged between 10 and 60 minutes with

Tobacco Control, Vol 25, No. 4 (July 2016): pg. 483-487. DOI. This article is (C BMJ Publishing Group and permission has been granted for this version to appear in e-Publications@Marquette. BMJ Publishing Group does not grant permission for this article to be further copied/distributed or hosted elsewhere without the express permission from BMJ Publishing Group. 
the majority of interviews at approximately 45 minutes. We supplemented the interview data with public documents on Zambia's economic development plans and tobacco investment. Key informants pointed our research team to the key strategic documents from the Zambian Development Agency that informed their work. In addition to documents identified by key informants we collected other public documents pertaining to Zambia's development agenda, such as reports produced by the United Nations Conference on Trade and Development. The study protocol received ethics approval by the Institutional Review Boards of McGill University, Morehouse University (American Cancer Society) and the University of Zambia. All interviews were transcribed verbatim and analyzed using thematic analysis. ${ }^{16}$ The transcripts were entered into NVivo qualitative software for data management. The qualitative analysis was conducted by the lead author and used both deductive coding (based on the interview questions) as well as inductive coding. The results were discussed with team members, two of whom were experienced Zambian researchers active in the health and tobacco area, for verification.

\section{Results}

One of the major initiatives of the Zambian government to attract investment was the creation of the Zambia Development Agency (ZDA) in 2006, with the mandate to "foster economic growth and development by promoting trade and investment in Zambia through an efficient, effective and coordinated private sector led economic development strategy". ${ }^{17}$ Tobacco export promotion is one of the country's priorities, now absorbed within the work of the ZDA, justified primarily by its importance to farmers:

...It is a key industry especially for the farmers ... We have more than twenty thousand small scale farmers growing tobacco at the moment meaning that each farmer is able to take care of about six members of the family and when we do the math we will actually see how important this sector is in this country and how critical this industry is in reducing poverty levels. (ZDA informant)

Tobacco production receives incentives in terms of machinery and agrichemical imports, on which "duty and VAT are not paid." The

Tobacco Control, Vol 25, No. 4 (July 2016): pg. 483-487. DOI. This article is @ BMJ Publishing Group and permission has been granted for this version to appear in e-Publications@Marquette. BMJ Publishing Group does not grant permission for this article to be further copied/distributed or hosted elsewhere without the express permission from BMJ Publishing Group. 
key informant from ZDA was not aware of the FCTC, and acknowledged that ZDA does get involved in trade and tobacco disputes in "bilateral and multilateral discussions ... in Geneva...articulating our interests."

The ZDA is also responsible for the governance of Multi-Facility Economic Zones (MFEZ) and Industrial Parks that were established in 2005 with investors from Japan and China. The MFEZs (special industrial zones to both export-oriented and domestic-oriented industries) were established to "create a platform for Zambia to achieve economic development by attracting significant domestic and foreign direct investment (FDI) through a strengthened policy and legislative environment," and are characterized by "the best features of free trade zones (FTZs), export processing zones (EPZs) and the industrial parks/zones concept". ${ }^{18}$ In addition to bolstering governance and infrastructure to create an attractive investment environment, the ZDA provides a list of investment incentives offered to investors who intend to establish operations in the MFEZs or whose investment aligns with Zambia's development priority sectors. There are seven MFEZ priority sectors and twelve general priority sectors including agroprocessing and manufacturing of agricultural products, including tobacco. The principal requirement to receive an investment incentive from the ZDA is outlined in article 56: "An investor investing not less than five hundred thousand United States Dollars or the equivalent in convertible currency, in a priority sector or product, is entitled to incentives as specified by or under the Income Tax Act or Customs and Excise Act". ${ }^{17}$ The priority given to agro-processing and manufacturing is supported by the objective to establish value addition within Zambia. ${ }^{19}$ including efforts "to increase tobacco processing for more value-added". ${ }^{11}$

This objective of value-addition is currently being enacted through government support for the establishment of a tobacco processing and manufacturing plant in the Makeni Industrial Park (an MFEZ) in Lusaka by Roland Imperial Tobacco Company (RITCO), a Zambian company. ${ }^{20-22}$ At present the plant is intended simply to process tobacco leaf. But, a senior staff person with the MFEZ noted, "in the long run [the company has] indicated it is in phases, in phase one they are processing and laying the ground work, and then when they get to phase three, that is when they begin to manufacturing the

Tobacco Control, Vol 25, No. 4 (July 2016): pg. 483-487. DOI. This article is (C) BMJ Publishing Group and permission has been granted for this version to appear in e-Publications@Marquette. BMJ Publishing Group does not grant permission for this article to be further copied/distributed or hosted elsewhere without the express permission from BMJ Publishing Group. 
finished product [cigarettes]." In a public pronouncement, the CEO of RITCO claimed "we invested more than USD \$8 million in our new cigarette plant in Lusaka, which can produce two billion cigarettes per year, or around twice the cigarettes sold in Zambia annually". ${ }^{22}$ This amount far exceeds the USD $\$ 500,000$ minimum investment that is required to qualify for the incentives outlined by the ZDA. ${ }^{17,19,23}$

Whether restricted to leaf processing only, or proceeding to finished product (not all Zambian informants thought this would be likely), the company would benefit from government support in the form of no tariffs or VAT on imported machinery or raw goods. As well, "the government is funding this [MFEZ] ... they had to put up a requisite structure [electricity, roads, water] to make sure that the place is conducive for our investors both local and foreign" (MFEZ informant). It would also be exempt from any tax on profits for the first 5 years, paying only fifty percent of the standard corporate rate for the next three and seventy-five percent for the following two years. Only after 10 years would profits be taxed at Zambia's normal corporate rate. These benefits would apply to tobacco, as to any other agro-industry product that comprise one of ZDA's priority investment areas, and to processed leaf or finished products regardless of whether they are meant for the domestic or export market. That these incentives could give an unfair advantage over other Zambian tobacco leaf processors or a manufacturer (one of our informants stated that another manufacturing plant was getting established outside of an MFEZ) "has not yet been discussed, because the primary objective of these zones is to promote investment" (MFEZ informant).

"We are working knowing we have been told [by ZDA] to win investors...we are being pushed that we need investors [yet] I know that it has been the objective of the government to regulate [tobacco] consumption...so you may say that if they are doing that then are contradicting that...We market [investment] on the marketing point of view not on the health point of view...If we say we look at the health point then we would be negative for us [and] we have to show the positive side" (MFEZ informant).

Our interviews with representatives from Zambia's Department's of Industry (DoI) and Foreign Trade (DoFT) similarly found that these departments were also actively encouraging tobacco companies to set

Tobacco Control, Vol 25, No. 4 (July 2016): pg. 483-487. DOI. This article is (C) BMJ Publishing Group and permission has been granted for this version to appear in e-Publications@Marquette. BMJ Publishing Group does not grant permission for this article to be further copied/distributed or hosted elsewhere without the express permission from BMJ Publishing Group. 
up processing and manufacturing facilities in Zambia. The participants explicitly stated that they encouraged the provision of investment incentives to make this happen, for both the domestic and international market Both department representatives viewed tobacco manufacturing as a potential growth area for Zambia's economic development objectives. This encouragement was situated in the development strategy targeting value addition (namely manufacturing of agricultural products grown in Zambia) within the economy: "the agricultural sector will continue to be a strategic area of focus in promoting economic growth, reducing poverty and creating employment". ${ }^{24}$ Since the closing of the British American Tobacco manufacturing plant in Lusaka in $2006,{ }^{25}$ all of the cured tobacco was being exported for manufacturing in other countries.

When asked about the role of the FCTC in the policies of their respective departments (i.e. DoI and DoFT), the participants only had a vague understanding of its provisions or what commitments Zambia had made to implementation. A high-level key informant from the DoFT was unsure whether the treaty was in force in Zambia and noted "implementation hasn't started yet". This statement may have been in reference to stalled comprehensive tobacco control legislation, although the treaty had come into force in Zambia in August 2008. It is difficult to identify whether there is a true lack of understanding of the FCTC and its relation to the economic policies of the country by these informants, or whether their government departments are intentionally acting contrary to its provisions. Our sense from the interviews was that the FCTC was simply not considered to be relevant to the work of either the DoI or the DoFT, and was situated as a singular Department of Health initiative. When we asked the participants about the relationship between investment incentives for tobacco processing and manufacturing and the health aspects of tobacco consumption, one participant stated that: "It is our view that the benefits to the economy will outweigh the health costs" (DoI informant).

Another participant, making the same argument as the interviewee from the MFEZ, noted "our concern is to promote industrial development and because smoking was a personal decision we are not concerned with the health aspects" (DoI).

Tobacco Control, Vol 25, No. 4 (July 2016): pg. 483-487. DOI. This article is @ BMJ Publishing Group and permission has been granted for this version to appear in e-Publications@Marquette. BMJ Publishing Group does not grant permission for this article to be further copied/distributed or hosted elsewhere without the express permission from BMJ Publishing Group. 
The view that Zambia's tobacco production, and even its potential future cigarette manufacturing, would not add to its domestic smoking rates was echoed by tobacco industry informants, one of whom was quite explicit:

"There is this myth that the more tobacco we grow here the more smokers we will have. We do not grow tobacco for local consumption but rather for the growing market like China. There is no correlation with the level of growing tobacco in Zambia to the level of smoking. It doesn't exist. In fact there is a reduction in smoking in Zambia (tobacco industry informant)."

The most recent WHO tobacco report on Zambia, however, estimates that in 2012 24\% of males were current cigarette smokers, $22 \%$ of them daily, an increase of 2 and 5 percentiles respectively over the previous year. ${ }^{26}$ Female rates remain considerably lower, but are rising amongst adolescents. ${ }^{27}$ When asked that, even assuming Zambian tobacco was strictly for export, it still meant someone else will be consuming a hazardous product, the response was swift, "even if we do not grow tobacco in Zambia, somebody else will grow it [and export it] so you see what I mean, it will still be there." The Tobacco Association of Zambia (TAZ), representing farmers, noted that "the harmful effects on the human being is not debatable, it has been proven, we have all seen it" but that "it all borders on educating the person, that you have a choice in life and should manage your life accordingly" (TAZ informant).

These qualitative findings provide important insights into the rationale used by members of the government's economic sector when developing policy pertaining to tobacco, which often resembles the arguments of Zambia's tobacco industry and farming representatives; and suggests that there is deep misalignment between FCTC commitments and efforts to implement the treaty across relevant sectors of government. The tension this creates was best captured in the somewhat wistful comment made by our MFEZ informant near the end of the interview: "I think somehow there must be harmonization of government policy; then that will make it much easier for stakeholders."

One of the salient conditions underlying policy misalignment and lack of harmonization is that tobacco control is under-resourced. There

Tobacco Control, Vol 25, No. 4 (July 2016): pg. 483-487. DOI. This article is (C) BMJ Publishing Group and permission has been granted for this version to appear in e-Publications@Marquette. BMJ Publishing Group does not grant permission for this article to be further copied/distributed or hosted elsewhere without the express permission from BMJ Publishing Group. 
will need to be great effort to strengthen the system of implementation within countries like Zambia. One individual serves as the FCTC focal point but is responsible for a diverse portfolio of responsibilities beyond tobacco control. Along with other African countries at the FCTC Conference of Parties meetings, Zambia has complained about the lack of resources to implement tobacco control. A senior policy worker in the Ministry of Health thought that one reason why the comprehensive tobacco control legislation has been stuck for four years is that "We had the challenge of funding, because initially tobacco was not on our agenda and ... we [had] different budget lines... [and] it gives us a gap because we don't have funds to use for that purpose". There is no multisectoral body in Zambia charged with FCTC implementation and the different sectors "are not coordinating properly" (Ministry of Health informant). Departments of Industry, Foreign Trade and Agriculture noted that they did not work with the Ministry of Health around issues of tobacco and tobacco control. There is, however, an active, but small, group of civil society organizations and individuals within government working in tobacco control, but it must contend with a politically active and highlyresourced tobacco industry whose own interests in 'coordinating' is about:

"...sitting together. You see look we agree on most of the things but because we do not sit together we assume that we don't agree. We need to sit together as an industry... The problem in this country is that we do not have an apex, one organization where all players meet for cross cutting issues" (tobacco industry informant).

\section{Discussion}

Our findings on the Zambia's tobacco investment incentives point to an urgent need for proponents of the FCTC (domestic and international) to engage with the ZDA, DoI and DoFT to generate economic policies that align with FCTC commitments. The question is how to do this?

The Zambian government, like many governments around the world, is fragmented when it comes to governing tobacco and tobacco control. This fragmentation exists not only internally but also at

Tobacco Control, Vol 25, No. 4 (July 2016): pg. 483-487. DOI. This article is @ BMJ Publishing Group and permission has been granted for this version to appear in e-Publications@Marquette. BMJ Publishing Group does not grant permission for this article to be further copied/distributed or hosted elsewhere without the express permission from BMJ Publishing Group. 
different levels whereby the DoI, DoFT and ZDA are linked with different economic development agencies within the United Nations system and the Department of Health is operating with relationships to the WHO and the Framework Convention Secretariat. Fragmentation is a not a new phenomenon and undergirds calls made within the United Nations System to "strengthen multisectoral and inter-agency responses for the full implementation of the WHO FCTC". ${ }^{28}$ To label the lack of communication, coordination and cooperation between sectors as fragmentation is only theoretically valid if there is underlying need to act collectively. In the case of FCTC implementation, fragmentation exists because comprehensive tobacco control implementation (invoking all components of the treaty including supply and demand measures) requires interventions in different sectors and levels of government. In this sense, FCTC implementation poses a collective action problem that challenges institutional designs that create departmental silos with minimal interaction and strong jurisdictional boundaries between sectors. In fact, the integrity of traditional departmental jurisdiction is reflected in the authority to "operate within a spatial and functional realm". ${ }^{29}$ A logical starting point to facilitate intersectoral working is to establish a forum for dialogue. The forum itself is not a panacea but rather an initial point of contact. Brazil presents a good example of how a high-level decision from the President created a forum (CONICQ - i.e. the intersectoral coordinating mechanism for the implementation of the FCTC) that brought together 13 different ministries and departments to work on FCTC implementation. ${ }^{30,31}$ It will likely require a high-level decision to create such a forum in Zambia. Another basic starting point for those working on FCTC implementation in countries like Zambia is to begin to establish and propagate norms embedded in the FCTC. In this case it will be the responsibility of proponents of tobacco control to reinforce the binding legal nature of commitments made to the FCTC to other sectors of government. The guidelines for Article 5.3 explicitly state, "Parties should not grant incentives, privileges or benefits to the tobacco industry to establish or run their business" (Article 5.3

guidelines, p. 8), which evidence from this research suggests they are presently violating in Zambia.

It is possible that the first reaction to our findings might be that the tobacco industry has coopted FCTC implementation by "capturing" the economic sector. Regulatory capture, "specifically the process

Tobacco Control, Vol 25, No. 4 (July 2016): pg. 483-487. DOI. This article is (C) BMJ Publishing Group and permission has been granted for this version to appear in e-Publications@Marquette. BMJ Publishing Group does not grant permission for this article to be further copied/distributed or hosted elsewhere without the express permission from BMJ Publishing Group. 
through which regulated (companies) end up manipulating state agencies that are supposed to control them", ${ }^{32}$ is a common occurrence in tobacco politics. ${ }^{33-35}$ We suggest that although this may be, and likely is, part of the scenario in Zambia, there are other contextual factors that create a pull towards providing investment incentives for tobacco manufacturing. Zambia is a tobacco producer and exporter. The priority for the country is to diversify its economic outputs while supporting value-addition in its processing and manufacturing within the country. In this context tobacco is a logical target for value-addition (leaf processing and manufacturing) given that the supply-chain is well established. This is not to say that the provision of investment incentives is good practice; in fact, we suggest the opposite. Understanding this context will allow tobacco control proponents to target the underlying logic used by government officials who are promoting tobacco production, while also developing an empathetic stance when working to develop collaborative relationships with other government sectors. Understanding this context provides the basis for remedying this policy misalignment from the perspective of FCTC implementation. There are numerous interventions that can address this misalignment between economic policy pertaining to tobacco and commitments to implement the provisions of the FCTC. The arguments used by our key informants in favor of bolstering tobacco manufacturing through government investment incentives suggests that discourse in the economic sector is largely influenced by the standard arguments (e.g. job loss/gain, revenue generation, personal choice) perpetuated by the tobacco industry over the years, particularly in tobacco growing countries. ${ }^{36,37}$ Studies like this one provide important information to sensitize tobacco control proponents to the perspectives and approaches being fostered outside of the health sector. This sensitization is particularly important as countries begin to implement intersectoral coordinating mechanisms for FCTC implementation as per Article 5.2. It is recognized that the political economic context must be confronted and engaged with by tobacco control proponents for any lasting success in tobacco control policy to be made. ${ }^{2,38-40}$

At a more abstract level, this study suggests a need to establish and integrate norms pertaining to the economics of tobacco and tobacco control. Our interviews revealed that the logic employed within the economic sector, that tobacco is a viable and sustainable economic

Tobacco Control, Vol 25, No. 4 (July 2016): pg. 483-487. DOI. This article is (C BMJ Publishing Group and permission has been granted for this version to appear in e-Publications@Marquette. BMJ Publishing Group does not grant permission for this article to be further copied/distributed or hosted elsewhere without the express permission from BMJ Publishing Group. 
commodity, still persists despite numerous studies to the contrary. ${ }^{41-43}$ The argument that tobacco is an export commodity and therefore not linked to the health of the population within the country is contrary to the intent of the FCTC to reduce tobacco consumption worldwide (and not simply in any given country). Without comprehensive tobacco control measures in place it is predicted that consumption among Zambians will increase. ${ }^{27,44-47}$ It is reported that RITCO is in discussion with Japan Tobacco Incorporated (JTI) to produce JTI brands for the Zambian market. ${ }^{22}$ RITCO itself has indicated that they will be developing new brands to be sold in the domestic market. The proliferation of tobacco products without the protection of comprehensive tobacco control measures will likely lead to dramatic increases in consumption.

Government investment incentives that support tobacco industry development are deeply problematic for FCTC implementation. This finding in Zambia's case, which we speculate is likely repeated in most other low-income tobacco-producing countries that are also Parties to the FCTC, points to an urgent need to foster whole-of-government FCTC implementation.

\section{What This Paper Adds}

- Successful implementation of the WHO Framework Convention on Tobacco Control (FCTC) will require whole-of-government (WoG) engagement.

- There continues to exist gross misalignments between the economic policies of tobacco producing countries like Zambia, who are providing investment incentives to support tobacco industry activity, and commitments made to implement the provisions of the FCTC.

- Providing investment incentives to stimulate tobacco processing and manufacturing is contrary to Article 5.3 of the FCTC and is a crucial component to be addressed by tobacco control proponents to reduce the supply of tobacco.

- Our study provides important insights into the underlying logic used by officials to justify investment incentives that support tobacco processing and manufacturing. 
NOT THE PUBLISHED VERSION; this is the author's final, peer-reviewed manuscript. The published version may be accessed by following the link in the citation at the bottom of the page.

Funding statement: This analysis is derived from research supported by the National Institute on Drug Abuse, the Fogarty International Center, and the National Cancer Institute of the National Institutes of Health under Award Number R01DA035158. The research findings do not necessarily represent the views of the funder.

Contributors: RLen, RL, RZ and FG conducted data collection. RLen and RL undertook data analysis. RLen wrote the first draft of the manuscript. JD, RLab and FG contributed to the conceptualization and writing of the manuscript.

Competing interests: None

\section{Contributor Information}

Raphael Lencucha, McGill University, Faculty of Medicine, School of Physical and Occupational Therapy, 3630 Promenade Sir William Osler, Montreal, QC, Canada, H3G 1Y5, Email: raphael.lencucha@mcgill.ca, Office Phone: (514) 398-4400 extension 00386, Fax: (514) 398-6360.

Jeffrey Drope, Economic and Health Policy Research, American Cancer Society, Atlanta, United States.

Ronald Labonte, Institute of Population Health, University of Ottawa, Ottawa, Canada.

Richard Zulu, Faculty of Medicine, University of Zambia, Lusaka, Zambia.

Fastone Goma, Faculty of Medicine, University of Zambia, Lusaka, Zambia.

Tobacco Control, Vol 25, No. 4 (July 2016): pg. 483-487. DOI. This article is (C BMJ Publishing Group and permission has been granted for this version to appear in e-Publications@Marquette. BMJ Publishing Group does not grant permission for this article to be further copied/distributed or hosted elsewhere without the express permission from BMJ Publishing Group. 
NOT THE PUBLISHED VERSION; this is the author's final, peer-reviewed manuscript. The published version may be accessed by following the link in the citation at the bottom of the page.

\section{References}

1. WHO. World Health Organization; 2003. WHO Framework Convention on Tobacco Control.

2. Lencucha R, Drope J, Chavez JJ. Whole-of-government approaches to NCDs: the case of the Philippines Interagency Committee-Tobacco. Health Policy Plan. 2014 Aug 5; :czu085.

3. Koivusalo M. The state of Health in All policies (HiAP) in the European Union: potential and pitfalls. J Epidemiol Community Health. 2010 Jun $1 ; 64(6): 500-503$.

4. Ollila E. Health in All Policies: From rhetoric to action. Scand J Public Health. 2011 Mar 1;39(6 suppl):11-18.

5. Zambia Tobacco Products Control Bill 2010. Draft 2010. 2010

6. Chavez JJ, Drope J, Lencucha R, McGrady B. The Political Economy of Tobacco Control in the Philippines: Trade, Foreign Direct Investment and Taxation. Quezon City: Action for Economic Reform, American Cancer Society. 2014

7. UNCTAD. Tax Incentives and Foreign Direct Investment: A Global Survey. UNCTAD; 2000.

8. Zee HH, Stotsky JG, Ley E. Tax Incentives for Business Investment: A Primer for Policy Makers in Developing Countries. World Dev. 2002 Sep;30(9):1497-1516.

9. Bronzini R, de Blasio G. Evaluating the impact of investment incentives: The case of Italy's Law 488/1992. J Urban Econ. 2006 Sep;60(2):327349.

10. UNDP. Human Development Report 2013. United Nations Development Program. 2013

11. UNCTAD. An Investment Guide to Zambia Opportunities and Conditions 2011. UNCTAD; 2011.

12. CBR. Africa Infrastructure Investment Report. Commonwealth Business Council. 2013

13. UNCTAD. FDI INFLOWS TO ZAMBIA AND NON-TRADITIONAL EXPORTS (2001-2012)

14. Baxter P, Jack S. Qualitative Case Study Methodology: Study Design and Implementation for Novice Researchers. Qual Rep. 2008 Dec;13(4):544-559.

15. Yin RK. Case Study Research: Design and Methods. SAGE Publications; 2013. p. 313.

16. Miles MB, Huberman AM. Qualitative Data Analysis: An Expanded Sourcebook. SAGE; 1994. p. 358.

17. ZDA. THE ZAMBIA DEVELOPMENT AGENCY BILL, 2006. Zambian Revenue Authority; 2006.

Tobacco Control, Vol 25, No. 4 (July 2016): pg. 483-487. DOI. This article is @ BMJ Publishing Group and permission has been granted for this version to appear in e-Publications@Marquette. BMJ Publishing Group does not grant permission for this article to be further copied/distributed or hosted elsewhere without the express permission from BMJ Publishing Group. 
18. Zambia Development Agency. Multi-Facility Economic Zone (MFEZ) [Internet] ZDA; [[cited 2014 Aug 10]]. Available from: http://www.zda.org.zm/content/mfez.

19. ZDA. Why invest in Zambia? Zambia Development Agency. 2012

20. Times of Zambia | Tobacco plant on cards in Lusaka MFEZ [Internet] [[cited 2014 Aug 26]];2014 Available from: http://www.times.co.zm/?p=14234.

21. Zambia Namutowe J. "Tobacco Processing Plant Coming." The Times of Zambia (Ndola) [Internet] In: Namutowe Judith., editor. [[cited 2014 Aug 26]]. Available from: http://allafrica.com/stories/201308220176.html.

22. Roland Imperial Tobacco Company Ltd [Internet] [[cited 2014 Sep 17]]; US-Television. 2014 Available from: http://www.ustelevision.tv/articles/roland-imperial-tobacco-company-Itd.

23. ZDA. Application Manual for Investors Certificate of Registration and other Licenses. Zambian Revenue Authority; 2012.

24. Government of Zambia; 2011. Sixth National Development Plan 20112015: Sustained Economic Growth and Poverty Reduction.

25. TJI. BAT to end cigarette manufacture in Lusaka. [[cited 2014 Sep 1]];Tobacco Journal International [Internet] 2006 Apr 4; Available from: http://www.tobaccojournal.com/BAT_to_end_cigarette_manufacture_i n_Lusaka.47685.0.html.

26. WHO. Geneva: World Health Organization; 2013. WHO Report on the Global Tobacco Epidemic, 2013: Country Profile Zambia.

27. ITC Project. ITC Zambia National Report: Findings from the Wave 1 (2012) Survey. University of Waterloo; 2014.

28. ECOSOC. United Nations system-wide coherence on tobacco control. United Nations Economic and Social Council; 2012.

29. Skelcher C. Jurisdictional Integrity, Polycentrism, and the Design of Democratic Governance. Governance. 2005;18(1):89-110.

30. Lee K, Chagas LC, Novotny TE. Brazil and the Framework Convention on Tobacco Control: Global Health Diplomacy as Soft Power. PLoS Med. 2010 Apr 20;7(4):e1000232.

31. Da Costa e Silva VL, Pantani D, Andreis M, Sparks R, Pinsky I. Bridging the gap between science and public health: taking advantage of tobacco control experience in Brazil to inform policies to counter risk factors for non-communicable diseases. Addiction. 2013;108(8):13601366.

32. Bó ED. Regulatory Capture: A Review. Oxf Rev Econ Policy. 2006 Jun $20 ; 22(2): 203-225$.

33. Collin J, Hill S. Corporate involvement in public health policy is being obscured. BMJ. 2013 May 28;346(may28 4):f3429-f3429.

Tobacco Control, Vol 25, No. 4 (July 2016): pg. 483-487. DOI. This article is (C BMJ Publishing Group and permission has been granted for this version to appear in e-Publications@Marquette. BMJ Publishing Group does not grant permission for this article to be further copied/distributed or hosted elsewhere without the express permission from BMJ Publishing Group. 
NOT THE PUBLISHED VERSION; this is the author's final, peer-reviewed manuscript. The published version may be

accessed by following the link in the citation at the bottom of the page.

34. Gilmore AB, McKee M, Collin J. The invisible hand: how British American Tobacco precluded competition in Uzbekistan. Tob Control. 2007 Aug $1 ; 16(4): 239-247$.

35. Gilmore A, Collin J, Townsend J. Transnational Tobacco Company Influence on Tax Policy During Privatization of a State Monopoly: British American Tobacco and Uzbekistan. Am J Public Health. 2007 Nov;97(11):2001-2009.

36. Glantz S, Gonzalez M. Effective tobacco control is key to rapid progress in reduction of non-communicable diseases. Lancet. 2012 Mar 31;379(9822):1269-1271.

37. Otanez MG, Mamudu HM, Glantz SA. Tobacco Companies' Use of Developing Countries' Economic Reliance on Tobacco to Lobby Against Global Tobacco Control: The Case of Malawi. Am J Public Health. 2009 Oct;99(10):1759-1771.

38. Chantornvong S, Collin J, Dodgson R, Lee K, McCargo D, Seddon D, et al. Political economy of tobacco control in low-income and middle-income countries: lessons from Thailand and Zimbabwe. Global Analysis Project Team. Bull World Health Organ. 2000;78(7):913-919.

39. Bump JB, Reich MR. Political economy analysis for tobacco control in lowand middle-income countries. Health Policy Plan. 2013 Mar $1 ; 28(2): 123-133$.

40. Drope J, Chavez JJ, Lencucha R, McGrady B. The Political Economy of Foreign Direct Investment: Evidence from the Philippines. Policy Soc. $2014 ; 33(2)$

41. Jha P, Chaloupka FJ. The economics of global tobacco control. BMJ. 2000 Aug 5;321(7257):358-361.

42. Jha P, Chaloupka FJ. Curbing the Epidemic: Governments and the Economics of Tobacco Control. World Bank Publications. 1999:140.

43. Warner KE. The economics of tobacco: myths and realities. Tob Control. 2000 Mar 1;9(1):78-89.

44. Blecher E, Ross H. Tobacco Use in Africa: Tobacco Control Through Prevention. Atlanta, GA: American Cancer Society; 2013.

45. Blecher $\mathrm{E}$. The impact of tobacco advertising bans on consumption in developing countries. J Health Econ. 2008 Jul;27(4):930-942.

46. Ross H, Blecher E, Yan L, Hyland A. Do cigarette prices motivate smokers to quit? New evidence from the ITC survey. Addiction. 2011 Mar $1 ; 106(3): 609-619$.

47. Chaloupka FJ, Straif K, Leon ME. Effectiveness of tax and price policies in tobacco control. Tob Control. 2010 Nov 29; tc.2010.039982.

Tobacco Control, Vol 25, No. 4 (July 2016): pg. 483-487. DOI. This article is (C BMJ Publishing Group and permission has been granted for this version to appear in e-Publications@Marquette. BMJ Publishing Group does not grant permission for this article to be further copied/distributed or hosted elsewhere without the express permission from BMJ Publishing Group. 